Foundation, will come under the financial charge of the College and will be raised to the status of a Department, with Dr. B. Katz, at present reader in experimental physiology, as professor.

Prof. Hill was awarded the Nobel Prize for Physiology and Medicine in 1922, and the Copley Medal of the Royal Society in 1948. During 1935-45 he was a secretary of the Royal Society and during 1945-46 he was the Society's foreign secretary. This is not the place to deal with Prof. Hill's world-famed researches in physiology, especially biophysics, or to chronicle his many activities in connexion with scientific advancement and education, except perhaps to mention that he was member of Parliament representing the University of Cambridge during 1940-45.

\section{Endeavour Prizes at the British Association}

ON August 9 at the British Association meeting in Edinburgh, H.R.H. the Duke of Edinburgh presented prizes to the winners in a scientific essay competition for young scientific workers less than twenty-five years of age. This was the second year of the competition, which was sponsored by Endeavour, a quarterly review of science published by Imperial Chemical Industries, Ltd. Altogether seventy-six essays were submitted, and the prize-winners (their ages shown in brackets) were as follows: First Prize of Fifty Guineas, B. C. Kilkenny (23), of Beaumont College, Old Windsor and New College, Oxford, and now a research student in the Physical Chemical Laboratory, Oxford, for an essay on "Biological Effects of Radiation" ; Second Prize of Twenty-Five Guineas, J. H. Pantin (21) (the son of Dr. C. E. A. Pantin, president this year of the Zoology Section of the British Association), of Oriel College, Oxford, for an essay on "Animal Locomotion"; Third Prize of Ten Guineas, P. G. Garner (24), of Cambridgeshire High School for Boys and King's College, London, and now a research student in physical chemistry at King's College, for an essay on "Chromatography and its Possibilities" ; Special Prize of Five Guineas (for a competitor under eighteen years of age), M. J. Sheridan (17), of Hornsey County School, for an essay on "Seaweeds and their Uses".

\section{Use of Fuel and Power Resources}

Mr. P. J. NoEL-Baker, Minister of Fuel and Power, has appointed a ccmmittee to consider the use of resources of fuel and power in Great Britain. The terms of reference are: "In view of the growing demands for all forms of fuel and power arising from full employment and the rearmament programme, to consider whether any further steps can be taken to promote the best use of our fuel and power resources, having regard to present and prospective requirements and in the light of technical developments". The membership of the committee is as follows: Viscount Ridley, member of the former Fuel and Power Advisory Council (chairman); Mr. Lincoln Evans, general secretary of the Iron and Steel Trades Confederation; Mr. N. W. Gardiner, technical director of Huntley and Palmers, Ltd.; Sir Claude Gibb, chairman and managing director of C. A. Parsons and Co., Ltd.; Prof. W. R. Hawthorne, professor of applied thermodynamics, University of Cambridge ; Prof. W. A. Lewis, professor of political economy, University of Manchester; Mrs. M. Mackintosh, tutor in sociology at Bedford College, University of London; and Miss M. R. Schofield, housing manager of Stoke Newington Borough Council.

\section{G. Farben Central Laboratory Index}

TeChNICAL information about chemical products marketed under trade names in Europe and America is available at the Technical Information and Documents Unit, Department of Scientific and Industrial Research, Lacon House, Theobalds Road, W.C.1. The information is contained in twenty-nine reels of microfilm and is a photographic facsimile of the I. G. Farben Central Laboratory Index. The index appears to have been compiled during the years 1933-43, although a fow additional notes are dated 1946, and it comprises more than 57,000 cards. The information is given in alphabetical order under trade names and includes the chemical name of each product or its analysis, and its constitution and application. In addition, information about patents and literature reference is given. Most of the entries refer to dyestuffs, but the index also covers resins, plastics, detergents, wetting agents, waterproofing and emulsifying agents, textile assistants, rubber accelerators, cellulose esters, synthetic rubber, oil additives, tannins, insecticides, solvents, pharmaceutical products and other commodities. The index can be inspected at the Technical Information and Documents Unit (Chancery 4411) by appointment and no charge is made for inspection. Photo copies of entries may be ordered and purchased.

\section{Odours of Minerals}

AN informative article on "The Odours of Minerals", by Dr. W. McCartney, has appeared in The International Perfumer (No. 3, 1951, pp. 7-10). The odours attributed to some solid bodies, which, having negligible vapour pressures, might be expected to be entirely odourless, are by no means imaginary, and have attracted attention since as early as 1798, when Fourcroy discussed the odours of metals. Later, in 1898, a study of the odours of a number of metals was described by Ayrton at a meeting of the British Association at Bristol ; he concluded that the odours were not those of the metals themselves but of impurities and substances produced, for example, by human breath and perspiration. Later work has substantiated Ayrton's conclusions, and has demonstrated that metal surfaces can adsorb and tenaciously retain traces of organic compounds such as mercaptans and thio-ethers. Another aspect of the same phenomenon concerns natural minerals. The odours emitted on striking white pebbles and other minerals such as quartz, agate and flint have been found to be caused by organic impurities. These impurities may be present as bituminous inclusions or may be derived from dust, lichens, moss or algæ, or from earth or mud; but contamination by organic matter, imparted by contact with human hands, is one of the chief causes of such odours. Brief contact with human skin imparts this property; the impurity is very tenaciously retained, and can only be removed by such drastic treatment as ignition at a dull red heat; washing with alkali or brushing seem to be ineffective. Other types of mineral odours, the odours sometimes noticed by mountaineers in the neighbourhood of landslides and avalanches, may be caused by the frictional heating of rock matter containing traces of pyrites or vegetable matter.

\section{Eelworm Pests of Mushrooms}

A PAPER, "Eelworms (Nematodes) as Pests of Mushrooms", by Charles A. Thomas and George H. Mitchell, is reprinted in Bull. No. 22 of the Mushroom 